\title{
FAKTOR-FAKTOR YANG MEMPENGARUHI REMARRIAGE DI LOMBOK TIMUR NTB
}

\author{
Nani' Khurul Jannah \\ UIN Syarif Hidayatullah Jakarta \\ n_khuruljannah91@gmail.com
}

\begin{abstract}
This research purpose is to know the influence of attitude toward remarriage, subjective norm to remarriage, perceived behavior control, relationship self-efficacy, age, sex, and period of divorce toward intention to remarriage in East Lombok, West Nusa Tenggara. This research shows that there are significant influence among attitude toward remarriage, subjective norm to remarriage, perceived behavior control, relationship self-efficacy, age, sex, an period of divorce toward intention to remarriage with variance of proportion about 40,8\%, whereas about $59,2 \%$ among other variables.
\end{abstract}

Keywords: Intention, Remarriage, Subjective Norm

\begin{abstract}
Abstrak
Tujuan dari penelitian ini adalah untuk mengetahui pengaruh dari sikap terhadap pernikahan kembali, norma subjektif terhadap pernikahan kembali, persepsi kontrol perilaku, efikasi diri dalam hubungan, usia, jenis kelamin, dan periode perceraian terhadap intensi menikah kembali di Lombok Timur, Nusa Tenggara Barat. Hasil penelitian menunjukkan adanya pengaruh yang signifikan dari seluruh variabel tersebut kepada pernikaha kembali dengan proporsi varians sebesar 40,8\%, sedangkan 59,2\% lainnya berasal dari variabel lain.
\end{abstract}

Kata Kunci: Intensi, Menikah Kembali, Norma Subjektif 


\section{PENDAHULUAN}

Pernikahan dan membina rumah tangga adalah salah satu aktifitas sentral manusia yang bertujuan untuk memperoleh kehidupan yang bahagia dan paripurna (Nisa, 2009). Menurut Olson dan DeFrain (2006) pernikahan sebagai komitmen emosional dan hukum dari dua orang untuk berbagi keintiman emosional dan fisik, berbagai tugas, dan sumber data ekonomi.

Pernikahan menawarkan sejumlah manfaat. Dibandingkan dengan single atau individu bercerai, pasangan suami istri menjalani gaya hidup sehat, hidup lebih lama, memiliki hubungan seksual yang lebih memuaskan, memiliki banyak kekayaan dan aset ekonomi, dan umumnya melakukan pekerjaan yang lebih baik untuk membesarkan anak-anak. Pasangan memiliki kesempatan untuk bahagia, saling mencintai pasangan dan diri mereka sendiri, menikmati hidup sendiri dan bersama-sama yang didirikan dalam pekerjaan mereka, menambah pertemanan serta cinta (Olson \& DeFrain, 2006).

Namun pada kenyataannya banyak pernikahan yang tidak berhasil. Kebanyakan orang menikah saat sedang jatuh cinta, tapi banyak juga dari mereka yang akhirnya bercerai (Olson \& DeFrain, 2006). Meski idealnya setiap orang mengharapkan pernikahan yang bahagia, tetapi adalah hal yang sangat tidak mudah dihindari dalam setiap hubungan yakni adanya sebuah masalah atau konflik, meski itu sangat kecil. Konflik-konflik yang terjadi pada pernikahan merupakan hal yang sangat wajar, namun ketidakmampuan pasangan suami istri dalam menyelesaikan masalah atau mengatasi konflik-konflik dapat mengakibatkan kegagalan dalam pernikahan (Papalia dalam Nisa, 2009).

Perceraian adalah hal yang mungkin ditempuh untuk mengakhiri pernikahan. Dari sisi psikologi, Hurlock (1980) mengatakan bahwa perceraian merupakan akumulasi dari penyesuaian masalah yang buruk, dan terjadi bila suami dan istri sudah tidak mampu lagi menyelesaikan masalah yang dapat memuaskan kedua belah pihak. Dampak dari perceraian salah satunya adalah kekacauan emosi sebelum dan sesudah perceraian itu terjadi, shock dan krisis selama perpisahan, bersedih atas hubungan yang berakhir dan periode kekacauan bersamaan dengan itu ada juga usaha individu yang bercerai untuk mencapai keseimbangan lagi misalnya dengan menikah kembali, bekerja lebih giat, atau berkumpul dengan teman dan keluarga. Sergen dan Flora (2005) mengatakan perceraian adalah suatu proses, dan setiap proses perceraian mempunyai 
pengaruhnya terhadap pasangan, anak, dan angora jaringan sosial. Perceraian dapat membawa perasaan gagal, bersalah, permusuhan dan mencaci diri sendiri, ditambah lagi tingkat depresi, sakit, dan kematian yang tinggi (Kitson \& Morgan; Thabes dalam Papilia, Old, \& Feldman, 2008). Namun tidak semua perceraian berdampak negatif, misalnya, ketika pernikahan sudah penuh konflik, maka pengakhirannya justru dapat meningkatkan kebahagiaan (Amato dalam Papalia, Old, \& Feldman, 2008).

Di Indonesia, salah satu provinsi yang masih banyak ditemui kasus perceraian adalah provinsi Nusa Tenggara Barat. Setiap tahun angka perceraian di NTB terus meningkat, dari data BPPKB NTB tahun 2011 tercatat 700 kasus kawin-cerai tahun 2010 dan 400 kasus hingga Juli 2011. Kasus perceraian terbanyak berada di Kabupaten Lombok Timur, seperti tahun 2009 tercatat 611 kasus, berikutnya tahun 2010 meningkat menjadi 724 kasus. Bahkan dalam data perceraian terbaru dari Pengadilan Tinggi Agama Mataram tahun 2011 di wilayah Lombok Timur yakni 791 kasus, dan untuk tahun 2012 hingga bulan September berjumlah 656 kasus.

Menurut Ratningdiah kepala BKKBN NTB, terdapat sedikitnya 13 faktor penyebab terjadinya perceraian di NTB yakni poligami, krisis akhlak, cemburu, kawin paksa, ekonomi, tidak ada tanggung jawab dari masingmasng pasangan, kawin di bawah umur, kekerasan jasmani, kekjaman mental, politis, gangguan pihak ketiga, tidak ada keharmonisan dan penyebab lainnya (Antara Mataram, 2011). Sedangkan dari data Pengadilan Tinggi Agama Mataram (2012) melaporkan, penyebab utama terjadinya perceraian di Lombok Timur adalah tidak ada tanggung jawab dari suami, tidak ada keharmonisan dalam rumah tangga, pengaruh ekonomi, adanya pihak ketiga, krisis akhlak, kawin paksa, poligami, KDRT.

Banyaknya angka perceraian mengakibatan banyak pula pernikahan kembali setelah perceraian di Lombok Timur. Orang yang telah bercerai akan kembali menikah dengan cepat. Sebab banyak orang yang setelah bercerai tidak dapat menghadapi kesendirian dan kegagalan (Cox dalam Bolang, 2012). Menikah kembali biasanya terjadi karena dua alasan yang berbeda: yaitu untuk mengurangi kesepian dan untuk memenuhi kebutuhan persahabatan (Bowers \& Bahr, 1989 dalam Vangelisti, 2003). Alasam lainnya yakni keinginan untuk mendapatkan pendamping lagi, untuk berbagi tanggung jawab dalam mengurus rumah tangga dan mengasuh anak, untuk mendapatkan rasa aman, memberikan orang tua baru pada anaknya dan untuk hubungan seksual (Mitchell dalam Hendarmini, 2004). 
Namun tidak semua orang yang bercerai inngin menikah kembali, mungkin disebabkan oleh trauma terhadap pernikahan sebelumnya. Pernikahan dikhianati pasangan, cemas, takut terjadi perpisahan kembali. Pernikahan kembali akan terbentuk dari sebuah keinginan atau kemungkinan subjektif seseorang untuk melakukan menikah kembali atau biasanya disebut dengan intensi. Intensi adalah keinnginan atau kemungkinan seseorang untuk melakukan sebuah perilaku, di mana perilaku yang dimaksud di sini adalah perilaku menikah kembali (remarriage). Ajzen dan Fishbein (1980, dalam Khan, 2007) menemukan bahwa intensi adalah prediktor yang sangat kuat dari perilaku. Secara keseluruhan, Ajzen (1991) mengusulkan bahwa orang akan menunjukkan intensi yang kuat terhadap perilaku ketika mereka memiliki sikap positif tentang hal itu, percaya bahwa orang lain berpikir mereka harus melakukannya, dan merasa memiliki kendali atas perilaku tersebut. Ketiga hal tersebut dinamakan sebagai sikap terhadap perilaku, norma subyektif, dan kontrol yang dirasakan atas perilaku (perceived control over behavior) (Ajzen \& Fishbein, 1980 dalam Khan, 2007).

Sikap terhadap remarriage adalah penilaian positif atau negatif seseorang terhadap perilaku menikah kembali setelah bercerai. Artinya semakin positif orang menilai tentang remarriage maka semakin besar intensi untuk menikah kembali, sebaliknya jika seseorang memiliki penilaian yang negatif terhadap pernikahan kembali maka intensi untuk remarriage akan menurun. Sikap positif pada perkawinan dapat mempengaruhi perilaku, begitu pula dengan sikap negatif pernikahan dapat mempengaruhi keyakinan tentang hubungan dengan pasangannya (Riggio \& Weiser, 2008, dalam Park, 2012).

Norma subjektif merupakan persepsi yang berasal dari penilaian tekanan sosial dari perilaku yang terlihat dibarengi dengan motivasi untuk mematuhi kelompok atau individu (Armitage \& Conner, 2001). Jadi kecenderungan seseorang untuk melakukan pernikahan kembali setelah perceraian bergantung pada persepsi seseorang tersebut terhadap penilaian masyarakat tentang perilaku menikah kembali, jika menurutnya masyarakat akan menilai pernikahan kembali setelah perceraian itu positif dan wajar serta masyarakat seperti mengharuskan perilaku tersebut, maka intensi untuk menikah kembali akan kuat.

Perceived behavioural control (PBC) adalah pengamatan/persepsi seseorang terhadap kemudahan dan kesulitan untuk menampilkan perilaku tertentu (Ajzen, 1991 dalam Armitage dan Conner, 2001) Jadi, seseorang 
akan cendering memiliki intensi yang kuat untuk menikah kembali, jika orang tersebut merasakan akan ada kemudahan dan kesempatan untuk melakukan perilaku menikah, dan jika perilaku tersebut dianggap sulit serta memiliki banyak hambatan maka intensi pun akan berkurang.

Relationship self-efficacy merupakan kemampuan seseorang dalam sebuah hubungan untuk pembentukan dan pemeliharaan hubungan (Morua \& Lopez, 2005, dalam Song, Lim, Foo, \& Uy, 2010). Dalam hubungannya dengan remarriage, relationship self-efficacy sangat dibutuhkan. Sebab bagaimana akan mendapatkan pernikahan yang lebih baik dari sebelumnya jika tidak memiliki keyakinan dan kemampuan untuk membentuk, memelihara, dan saling menjada dalam sebuah hubungan. Jadi, dapat diasumsikan bahwa semakin tinggi relationship selfefficacy seseorang maka semakin tinggi pula intensi remarriage, sebaliknya semakin rendah relationship self-efficacy seseorang semakin rendah pula intensi remarriage-nya.

Variabel demografi yang berpengaruh signifikan terhadap intensi adalah usia. Dalam penelitian Marcus dan Winnie (2009) dikatakan bahwa di Cina intensi remarriage dipengaruhi usia, kepuasan atas status kesendirian, kemampuan koping terhadap status duda, kebutuhan seksual, keburuhan untuk mendapatkan dukungan emosi. Selain usia, jenis kelamin dan lama bercerai juga sebagai variabel demografi yang mungkin berpengaruh terhadap intensi remarriage, meski dalam penelitian Marcus dan Winnie (2009) bahwa lama bercerai tidak berpengaruh namun penting dirasakan sebab penulis melihat ada beberapa penyesuaian yang dilakukan setelah bercerai yang mungkin dapat mempengaruhi niat seseorang untuk menikah kembali.

Ajzen (1991) mengatakan:

-Intentions are assumed to capture the motivational factors that influence a behavior; they are indications of how hard people are willing to try, of how much of an effort they are planning to exert, in order to perform the behavior."

Ada dua teori yang menjelaskan tentang intensi yakni Theory of reasoned action (TRA) dan Theory of planned behavior (TPB).

Dalam TRA (Fishbein \& Ajzen, 1975) dikatakan bahwa terdapat dua determinan yang berasal dari faktor personal (sikap terhadap perilaku) dan faktor pengaruh lingkungan (norma subjektif). TRA juga cukup berhasil jika diaplikasikan pada perilaku yang di bawah kendali diri sendiri. Jika perilaku tersebut sepenuhnya di bawah kendali atau kemauan individu, meski ia sangat termotivasi oleh sikap dan norma subjektifnya, ia mungkin tidak 
akan secara nyata menampilkan perilaku tersebut. Sebaliknya, TPB dikembangkan untuk meprediksi perilaku-perilaku yang sepenuhnya tidak di bawah kendali individu (Achmat, 2010).

Dalam TPB secara umum, seseorang memiliki intensi untuk mewujudkan perilaku ialah ketika mereka menilai positif, ketika mereka mengalami desakan sosial untuk mewujudkannya, dan ketika mereka percaya bahwa mereka memiliki maksud dan kesempatan untuk melakukannya (Ajzen, 2005).

Kerangka kerja dari TPB dapat dilihat pada gambar di bawah ini:

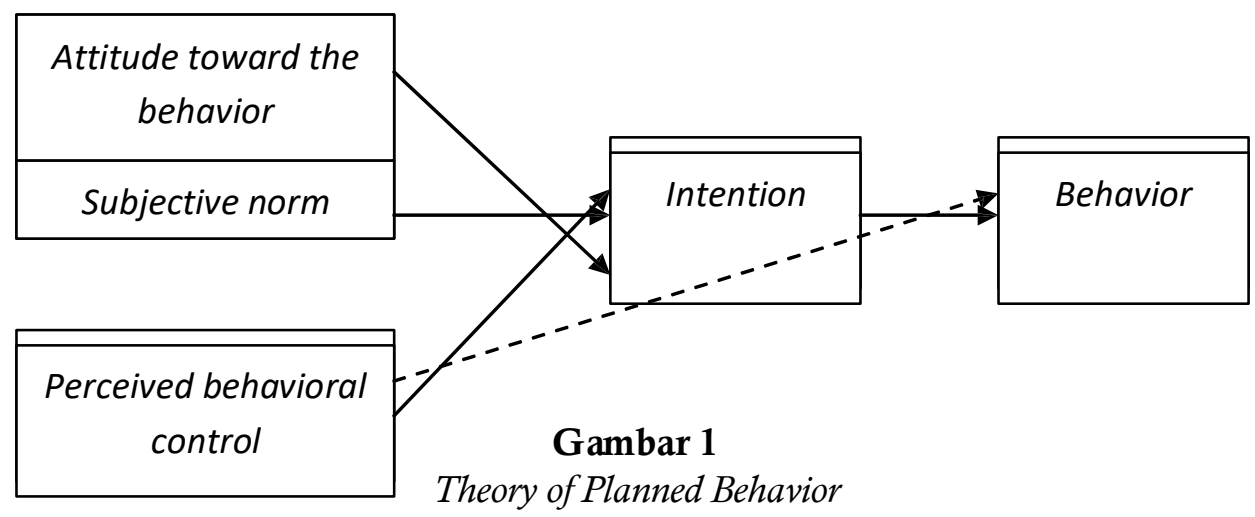

Bagan di atas menunjukkan bahwa TPB memiliki dua hal yang utama yakni: pertama, TPB berasumsi bahwa PBC memiliki implikasi motivasional bagi intensi. Artinya seseorang yang percaya apakah mereka tidak memiliki sumber atau kesempatan untuk mewujudkan perilaku tertenu sepertiya tidak akan mewujudkan intensi berperilaku, walaupun jika mereka memiliki sikap terhadap perilaku yang baik dan percaya pentingnya orang lain akan menerima perwujudan mereka. Kedua, kemungkinan hubungan yang langsung antara PBC dan intensi. Artinya perwujudan perilaku tidak hanya bergantung pada motivasi untuk melakukannya, namun juga melalui kontrol adekuat terhadap perilaku yang dipertanyakan. PBC dapat mempengaruhi perilaku secara tidak langsung, melalui intensi, dan dapat pula digunakan untuk meprediksi perilaku secara langsung karena dapat dianggap perwakilan atau bagian subtitusi untuk mengukur kontrol sebenarnya.

Dalam penelitian ini, teori yang digunakan adalah TPB. Teori ini digunakan karena mengacu pada penelitian sebelumnya tentang perbedaan intensi untuk menikah pada orang yang melakukan kohebisitas di Amerika 
dan Australis oleh Kahn (2007). Pada penelitian tersebut digunakan TPB untuk melihat intensi menikah seseorang. Asumsinya, seseorang akan menunjukkan intensi yang kuat terhadap perilaku ketika mereka memiliki sikap positif tentang hal itu, percaya bahwa orang lain berpikir mereka harus melakukannya (norma subjektif), dan merasa bahwa mereka memiliki kendali atas perilaku tersebut (Khan, 2007).

\section{METODE}

Populasi dalam penelitian ini adalah semua orang yang bercerai hidup (orang yang bercerai saat pasangan masih sama-sama hidup atau tidak dipisahkan kematian pasangan), belum menikah kembali, dapat melakukan baca dan tulis, serta berdomisili di kabupaten Lombok Timur, Nusa Tenggara Barat. Sampel yang digunakan yakni janda dan duda belum menikah kembali yang tinggal di kecamatan Sakra Barat, Sakra Timur, Sakra Pusat, Jerowaru, Keruak, Selong, Sikur, dan Aik Mel, berjumlah 122 orang.

Teknik pengambilan sampel yang digunakan dalam penelitian ini adalah teknik non probability sampling, dengan cara accidental sampling, di mana setiap individu dalam populasi tidak mendapat kesempatan yang sama untuk terpilih menjadi sampel penelitian.

\section{Skala intensi remarriage}

Pengukuran intensi untuk menikah kembali menggunakan Intent to Marry Scale (IMS), skala ini diambil dari salah satu konstrak sebuah alat ukut yakni Marriage Attitudes Expectation Scale (MAES) yang dikembangkan oleh Park (2012). IMS terdiri dari 7 item yang mengukur langsung intensi untuk menikah, namun karena ada salah satu item yang maksud dari pernyataannya sama dengan item yang lain, maka oleh penulis dikurangi jumlahnya menjadi 6 item.

Setelah dilakukan uji validitas menggunakan CFA model satu faktor, dan menghasilkan model fit dengan chi-square $=9,42, \mathrm{df}=8, p$-value $=$ 0,30815 dan RMSEA $=0,030$. Nilai $p>0,05$ (tidak signifikan) menunjukkan bahwa model fit,artinya model dengan satu faktor (unidimensional) dapat diterima, bahwa seluruh item mengukur satu dimensi saja yakni intensi remarriage. Namun berdasarkan muatan faktor, beberapa item pada model ini tidak memenuhi syarat atau tidak signifikan sehingga item yang dapat diterima hanya dua item yakni item 1 dan 4 . Oleh 
sebab itu, penulis memutuskan untuk melakukan modifikasi pada model dengan membuang salah satu item dari dimensi tersebut yang memiliki nilai $t$ paling rendah, yakni item nomor 5 .

Setelah membuang item nomor 5 , penulis melakukan analisis CFA model satu faktor kembali pada item nomor 1, 2, 3, 4, dan 6. Maka didapatkan model fit dengan chi-square $=9,42, \mathrm{df}=5, p$-value $=0,09361$, dan RMSEA $=0,088$, artinya seluruh item mengukur satu dimensi saja yakni intensi remarriage.

\section{Skala sikap terhadap remarriage}

Sikap terhadap remarriage diukur menggunakan General Attitudes Marriage Scale (GAMS) yang dikembangkan juga oleh Park (2012). GAMS berjumlah 18 item. GAMS mengarah pada dua faktor yang mencerminkan sikap positif dan sikap negatif terhadap pernikahan. Determinan yang dominan pada GAMS adalah -Sikap Positif\| terhadap pernikahan, -Sikap Negatif\| terhadap pernikahan dan reaksi afektif terhadap pernikahan khususnya tentang -Ketakuran dan Keraguanll.

Setelah dilakukan uji validitas menggunakan CFA model satu faktor. Hasil yang didapatkan yakni chi-square $=252,65, \mathrm{df}=90, p$-value $=0,00000$, dan RMSEA $=0,126$. Karena nilai $p<0,05$ (signifikan) sehingga model menjadi tidak fit, maka penulis melakukan modifikasi pada model, dan hasilnya adalah chi-square $=96,80, \mathrm{df}=77, p$-value $=0,06311$, dan RMSE $=$ 0,047 . Nilai $p>0,05$ (tidak signifikan) sehingga model menjadi fit, yang artinya model dengan satu faktor (unidimensional) dapat diterima, bahwa seluruh item mengukur satu dimensi saja yaitu sikap terhadap pernikahan kembali (remarriage).

Dengan demikian secara keseluruhan berdasarkan muatan dan jumlah korelas, item yang didrop yakni item didrop yakni item nomor 2, 8 , $9,11,14,15$, artinya item-item ini tidak dapat diikuti dalam analisis perhitungan skor faktor.

\section{Skala norma subjektif terhadap remarriage}

Untuk mengukur norma subjektif terhadap remarriage, penulis menggunakan alat yang disusun sendiri. Mengacu pada teori Ajzen (1988) di mana dalam teori tersebut ada dua aspek yang diukur yakni normative belief dan motivational to comply. 
Skala ini memberikan 10 item pernyataan tentang norma subjektif pada remarriage, di mana variabel ini terdiri dari dua dimensi yakni 
normative belief (item nomor 1 sampai 5) dan motivational to comply (item nomor 6 sampai 10$)$.

Berdasarkan hasil analisis CFA model satu faktor pada dimensi normative belief didapatkan chi-square $=16,70, \mathrm{df}=5, p$-value $=0,00511$, dan RMSEA $=0,143$. Karena nilai $p<0,05$ (signifikan) sehingga model menjadi tidak fit, maka penulis melakukan modifikasi pada model, dan hasilnya adalah chi-square $=6,36, \mathrm{df}=4, p$-value $=0,17393$, dan $\mathrm{RMSEA}=0,072$. Nilai $p>0,05$ (tidak signifikan) sehingga model menjadi $f i t=$, yang artinya model dengan satu faktor (unidimensional) dapat diterima, bahwa seluruh item mengukur satu dimensi saja yaitu normative belief.

Untuk dimensi motivational to comply, didapatkan juga model tidak fit dengan chi-square $=11,64, \mathrm{df}=5, p$-value $=0,04003$, dan $\mathrm{RMSEA}=0,108$. Agar model menjadi fit, atau model dengan satu faktor dapat diterima maka akan dilakukan modifikasi pada model, sehingga hasilnya adalah chi-square $=6,36, \mathrm{df}=4, p$-value $=017393$, dan RMSEA $=0,072$. Nilai $p>0,05$ (tidak signifikan) maka model menjadi fit, jadi seluruh item mengukur satu dimensi saja yaitu motivational to comply.

Jadi secara keseluruhan item yang tidak valid pada variabel norma subjektif adalah item nomor 5 dan 9.

\section{Skala perceived behavior control}

Perceived behavior control terhadap remarriage diukur dengan alat ukur PBC yang disusun sendiri oleh penulis. Mengacu pada teori Ajzen (1991m dalam Armitage dan Conner, 2001) di mana aspek yang diukur adalah hal-hal yang mendorong dan menghambat atau menyulitkan intensi seseorang untuk menikah kembali, kemampuan dan kesempatan yang dimiliki untuk menampilkan tingkah laku tertentu. Dalam teori ini terdapat dua dimensi yakni control belief dan power of control belief, namun yang diukur dalam penelitian ini hanya control belief saja.

Jumlah item dalam skala ini adalah 7 item yang ada bersifat unidimensional, atau hanya mengukur dimensi control belief saja. Berdasarkan hasil analisis CFA model satu faktor didapatkan model fit dengan chi-square $=16,69, \mathrm{df}=14, p$-value $=0,27301$, dan $\mathrm{RMSEA}=0,041$, artinya seluruh item hanya mengukur satu dimensi saja yaitu control belief.

Skala relationship self-efficacy

Pengukuran relationship self-efficacy menggunakan Relationship Efficacy 


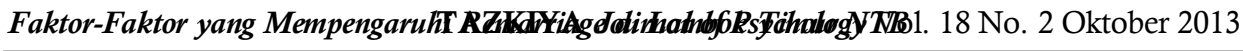

Measure Fincham, Harold, \& Gano-Phillips (2000). Terdiri dari 7 item 
dalam bentuk likert mulai dari sangat tidak setuju sampai sangat setuju pada pernyataan yang disajikan. Skala ini dimodifikasi pula dengan memberi tambahan dimensi relationship self-efficacy menurut Lopez, Morua, \& Rice (2007) yakni mutuality, emotional control, dan differentiation, sehingga total pertanyaan menjadi 14 item yang disusun sendiri oleh penulis.

Dalam pengujian analisis CFA satu faktor penulis membagi 14 item ke dalam tiga dimensi relationship self-efficacy yakni mutuality (item nomor 1 sampai 4) dengan hasil chi-square $=2,83, \mathrm{df}=2, p$-value $=0,24290, \mathrm{RMSEA}$ $=0,060$, dan model fit. Namun karena ada salah satu item yang bermuatan negatif maka dilakukan uji ulang setelah membuang item negatif tersebut dan hasilnya adalah model fit dengan chi-square $=0,00, \mathrm{df}=0, p$-value $=$ 1.00000 , dan RMSEA $=0,000$. Emotional control (item nomor 5 sampai 9) didapatkan chi-square $=12,07, \mathrm{df}=5, p$-value $=0,03383$, dan $\mathrm{RMSEA}=$ 0,111 , karena nilai $p<0,05$ (signifikan) sehingga model menjadi tidak fit, maka penulis melakukan modifikasi pada model, dan hasilnya adalah chisquare $=5,14, \mathrm{df}=4, p$-value $=0,27321$, dan $\mathrm{RMSEA}=0,050$. Nilai $p>0,05$ (tidak signifikan). Differentiation (item nomor 10 sampai 14) didapatkan model fit dengan chi-square $=7,98, \mathrm{df}=5, p$-value $=0,15746$, dan $\mathrm{RMSEA}=$ 0,072 .

Berdasarkan analisis hasil CFA model satu faktor di atas, dapat disimpulkan secara keseluruhan item yang dieliminasi pada variabel relationship self-efficacy adalah item nomor 1,8 , dan 13 artinya item tersebut tidak dapat diikutkan dalam perhitungan skor faktor.

\section{HASIL}

Responden didominasi oleh janda dan duda yang berusia dewasa awal berjumlah 103 orang $(84,4 \%)$, dilanjutkan dengan responden berusia dewasa mdya 13 orang $(10,7 \%)$, kemudian disusul oleh janda dan duda berusia remaja akhir berjumlah 5 orang $(4,1 \%)$ dan terakhir responden dengan usia dewasa akhir 1 orang $(0,8 \%)$, Berdasarkan jenis kelamin, dapat dilihat bahwa responden perempuan $(73,8 \%)$ lebih banyak daripada laki-laki $(26,2 \%)$. Kemudian, dilihat dari lama perceraian, responden yang masa perceraiannya kurang dari 6 bulan berjumlah 10 orang (8,2\%), 6-18 bulan berjumlah 39 orang (32\%), dan lebih dari 18 bulan sejumlah 73 orang $(59,8 \%)$.

Dari hasil regresi ternyata diperoleh $\mathrm{R}$ square sebesar 0,408 atau $40,8 \%$. Artinya, proporsi varian intensi remarriage yang dijelaskan oleh 
semua independent variable adalah sebesar $40,8 \%$, sedangkan $59,2 \%$ sisanya dipengaruhi oleh variabel lain di luar penelitian. Hipotesis mayor yang menyatakan ada pengaruh sikap terhadap remarriage, norma subjektif, perceived behavior control, relationship self-efficacy, dan variabel demografi terhadap intensi remarriage dapat diterima untuk kelompok janda dan duda. Dari hasil regresi di atas, hanya koefisien sikap, norma subjektif, relationship self-efficacy, jenis kelamin, dan usia yang signifikan, sedangkan sisanya tidak, dilihat dari proporsi varian variabel yang signifikan memberi sumbangan dari yang terbesar hingga yang terkecil ialah variabel sikap $(25,2 \%)$, variabel norma subjektif $(6 \%)$, dan variabel demografi jenis kelamin memberikan sumbangan 5\% terhadap intensi remarriage janda dan duda di Lombok Timur.

Kelompok perempuan (janda) ternyata diperoleh $\mathrm{R}$ square sebesar 0,337 atau $33,7 \%$. Artinya proporsi varian intensi remarriage pada janda yang dijelaskan oleh semua independent variabel adalah sebesar 33,7\%. Dari proporsi varians dapat dilihat sikap terhadap remarriage memberikan sumbangan sebesar $23,5 \%$ variabel norma subjektif menyumbang $4,2 \%$, dan relationship self-efficacy memberikan sumbangan $3,4 \%$ terhadap intensi remarriage janda di Lombok Timur.

Dari hasil regresi responden laki-laki (duda) ternyata diperoleh $\mathrm{R}$ square sebesar 0,497 atau 49,7\%. Artinya proporsi varian intensi remarriage pada duda yang dijelaskan oleh semua independent variable adalah sebesar 49,7\%. Berdasarkan koefisien regresi variabel yang mempunyai pengaruh yang signifikan itu adalah hanya norma subjektif, dan sumbangannya terhadap intensi remarriage pada duda di Lombok Timur adalah sebesar $33,6 \%$.

Berdasarkan hasil uji hipotesis penelitian, maka kesimpulan yang diperoleh dari penelitian ini adalah: Ada pengaruh yang signifikan dari seluruh independent variable dan variabel demografi yaitu, sikap terhadap remarriage, norma subjektif, perceived behavior control, relationship self-efficacy, usia, jenis kelamin, dan lama perceraian terhadap intensi remarriage janda- dua pasca bercerai di Lombok Timur. Selain melihat secara keseluruhan, penulis juga mengukur intensi remarriage pada janda dan duda dengan cara terpisah. Berdasarkan hasil hipotesis mayor, intensi remarriage pada janda yang dipengaruhi independent variable adalah 33,7\% sedangkan untuk duda sebesar $49,7 \%$. Dari koefisien regresi, variabel yang berpengaruh signifikan terhadap 
intensi remarriage pada janda dan duda secara keseluruhan adalah sikap terhadap remarriage, norma subjektif pada remarriage, relationship self- 
efficacy, usia, dan jenis kelamin. Sedangkan jika dilihat pada masing-masing kelompok, variabel yang signifikan pada koefisien regresi kelompok janda yakni variabel sikap terhadap remarriage, norma subjektif pada remarriage, dan relationship self-efficacy. Pada kelompok duda koefisien regresi yang signifikan hanya sikap saja.

\section{DISKUSI}

Variabel sikap terhadap remarriage memiliki pengaruh yang signifikan terhadap intensi untuk menikah kembali, baik dilihat secara keseluruhan maupun terpisah kelompok duda atau janda saja. Artinya, semakin positif sikap seseorang terhadap remarriage, maka semakin tinggi pula intensi untuk menikah kembali dan sebaliknya, semakin negatif sikap seseorang terhadap remarriage semakin rendah pula intensi untuk menikah kembali. Hal ini sesuai dengan penjelasan teori intensi menurut Fishber dan Ajzen (1975) yaitu jika sikap seseorang lebih menguntungkan (positif) terhadap suatu objek atau perilaku, semakin tinggi pula intensi seseorang tersebut untuk melakukan perilaku dan sebaliknya.

Dalam penelitian ini sikap terhadap remarriage bernilai positif, artinya orang-orang menilai bahwa menikah kembali itu sah-sah saja. Hal ini berlawanan dengan teori yang mengatakan bahwa setelah bercerasi orangorang akan cenderung menilai pernikahan itu negatif (umumnya wanita). Terlebih pada wanita, di mana pada dasarnya wanita yang berpisah atau bercerai cenderung menggambarkan dirinya berada pada keadaan yang kurang nyaman dan kurang menyenangkan dibandingkan dengan wanita yang masih menikah (Buehlman, Gottman, \& Katz, 1992). Hal tersebut mengindikasikan bahwa perceraian merupakan suatu peristiwa yang traumatis (Nisa, 2009). Lebih lanjut lagi jika dilihat dari faktor penyebab perceraian terbanyak di Lombok selain nikah muda yakni faktor ekonomi dan kurangnya komunikasi dalam keluarga, di mana banyak perempuan di Lombok yang ditinggalkan merantau oleh suami dan tak jarang yang dari mereka ditinggalkan tanpa kabar dan nafkah selama berbulan-bulan atau bahkan bertahun-tahun, harusnya hal-hal tersebut dapat mempengaruhi sikap terhadap intensi remarriage.

Sikap positif ini terjadi selain mungkin karena usia respondek yang masih muda yakni pada kisaran 19-40 tahun (dewasa awal) dan 16-18 tahun 
(remaja) hingga masih banyak peluang bagi mereka untuk menikah kembali. Dalam masyarakat Lombok Timur terdapat paradigma yang 
semakin hari makin berkembang yakni janda lebih menarik untuk dinikahi dan beberapa laki-laki di Lombok cenderung lebih memilih janda untuk dinikahi atau hanya sekedar dijadikan pacar, sehingga perempuan di Lombok (khususnya Lombok Timur) cenderung tidak memiliki kekhawatiran sebagai janda bahkan banyak juga dari mereka yang bangga menjadi janda. Dalam penelitian lain yang juga membahas tentang pola tradisi kawin cerai pada masyarakat Lombok, Nusa Tenggara Barat yang dilakukan oleh Syarfuddin dan Ismail (2000), menemunak 86,9\% janda kawin cerai di suku Sasak tidak melakukan pencegahan agar perceraian tidak terjadi. Bahkan mereka menerima dengan rasa pasrah kepurusan yang diberikan oleh suaminya. Posisi kaum wanita dalam masyarakat sangat lemah, sehingga suami cenderung seenaknya menolak keinginan dari suaminya dan menerima keputusan yang dilakukan oleh suaminya (Muaz

1995, dalam Syarfuddin dan Ismail, 2000). Pergeseran nilai budaya tentang perceraian dan pandangan orang terhadap status janda yang sudah tidak tabu lagi juga mungkin menyebabkan sikap positif terhadap remarriage terlebih di Lombok Timur fenomena kawin cerai itu biasa terjadi sehingga telah terjadi budaya internal pada suku Sasak sendiri (Wahyudi, 2004). Menurut Purwata (1994) juga mengatakan bahwa kawin cerai, poligami, kawin musiman, cerai musiman, sudah menjadi tradisi dalam kehidupan masyarakat suku Sasak Lombok (dalam Syarfuddin dan Ismail, 1997).

Selanjutnya, variabel norma subjektif pada remarriage jika dilihat secara keseluruhan memiliki pengaruh yang signifikan pula terhadap intensi remarriage. Artinya semakin tinggi norma subjektif seseorang semakin tinggi pula intensi untuk menikah kembali setelah perceraian. Sama halnya dengan sikap, norma subjektif juga merupakan salah satu pembentuk dari intensi. Dalam theory of reasoned action (TRA), intensi seseorang untuk melakukan suatu perilaku ditentukan oleh dua faktor yakni sikap terhadap perilaku (attitude toward behavior) dan norma subyektif (subjective norm) mengenai perilaku (Fishbein \& Ajzen, 1975).

Pada penelitian yang dilakukan oleh Khan (2007) tentang faktorfaktor yang mempengaruhi intensi menikah pada orang yang melakukan kohesibitas di Amerika dan Australia, didapatkan bahwa intensi untuk menikah pada waita Australia lebih besar dipengaruhi oleh sikap dan norma subjektifnya. Hal tersebut terlihat juga pada penelitian ini, di mana norma subjektif remarriage pada janda berpengaruh signifikan juga terhadap intensi 
menikah kembali, sedangkan pada kelompok duda tidak signifikan. Hal ini mungkin disebabkan oleh pengaruh budaya, yakni pada kebanyakan wanita 
timur (khususnya perempuan suku Sasak) cenderung lebih terikat pada keluarga atau orang-orang yang dianggap penting baginya seperti sahabat, rekan kerja, dan sebagainya, serta jumlah responden laki-laki yang sangat sedikit.

Lain halnya dengan duda yang cenderung lebih bebas dan memiliki otoritarianisme sendiri untuk melakukan pernikahan kembali atau tidak. Kebebasan tersebut terbentuk selain karena laki-laki adalah yang menafkahi istri, pasca bercerai duda juga menjadi lebih bebas, biasanya lebih kreatif dan produktif, serta laki-laki juga tidak memiliki kecemasan terhadap status dua karena mereka masih memiliki banyak peluang untuk menikah kembali. Selain itu, dilihat dari budaya menarik pada suku Sasak, menurut Zuhdi (2011, dalam Zuhdi, Anwar, Taufik, Lestaro, dan Muid, 2011) mengatakan bahwa laki-laki memiliki posisi yang superior dan wanita sangat inferior. Dalam hal ini laki-laki harus memiliki kesiapan yang kuat secara mental dan materi untuk dapat melarikan (merariq) calon istri, karena dalam suku Sasak wanita (perawan maupun janda) memiliki harga dalam proses tawar-menawas uang pisuke (jaminan) yang harus disepakati oleh kedua belah pihak keluarga. Bisa jadi hal-hal tersebutlah yang mempengaruhi norma subjektif seorang duda untuk menikah kembali, di mana pada norma subjektif terdapat keyakinan normatif dan motivational to comply. Jadi meski orang lain menuntur untuk menikah kembali, maka norma subjektif tersebut akan terabaikan karena laki-laki memiliki banyak peluang untuk pernikahan selanjutnya. Begitupun dengan seseorang yang significant others-nya tidak menghendaki untuk menikah kembali. Jika menurutnya orang lain tidak akan setuju dengan pernikahan selanjutnya, namun orang tersebut memiliki keyakinan dan kemampuan untuk menikah kembali maka norma subjektif pun akan terabaikan juga. Sebab dalam tradisi merariq seorang laki-laki boleh membawa perempuan (calon istri) tanpa persetujuan orang tua maupun kerabat dekatnya terlebih dahulu, dan disinilah letak superioritas laki-laki Sasak untuk menunjukkan sikap kejantanan dan mempertahankan harga diri (Zuhdi, 2011 dalam Zuhdi, dkk, 2011).

Relationship self-efficacy memiliki pengaruh juga terhadap intensi remarriage di Lombok Timur dengan propori varians memberi sumbangan hanya 1,9\% namun tidak signifikan. Lain halnya dengan kelompok janda relationship self-efficacy memiliki pengaruh yang signifikan terhadap intensi remarriage dan sumbangan proporsi varians juga signifikan sebesar 3,4\%. Hal ini menunjukkan bahwa hipotesis awal dapat diterima. Namun pada 
kelompok duda, relationship self-efficacy tidak memiliki pengaruh yang signifikan. Pada penelitian sebelumnya dikatakan bahwa, dibandingkan dengan laki-laki, rata-rata perempuan lebih terampil dalam memberikan dukungan emosional (Goldsmith \& Dun, 1997; Kunkel \& Burleson, 1988 dalam Frederick, Lopez, Monia, Kenneth, \& Rica, 2007) dan bahwa perempuan lebih cenderung untuk menggunakan strategi pemeliharaan hubungan seperti keterbukaan diri, positif, keterbukaan, jaminan, dan berbagit tugas (Canary \& Stafford, 1922; Dainton \& Stafford, 1933; Murstein \& Addler, 1955; Ragsdale, 1966; Stafford, Dainton, \& Haas, 2000 dalam Frederick, dkk, 2007), kolektif, temuan ini menunjukkan bahwa perempuan pada umumnya dapat memegang kuat keyakinan tentang keterampilan pemeliharaan hubungan mereka (Frederick, dkk, 2007).

Selain itu laki-laki juga cenderung untuk lebih mementingkan kebutuhan seksual yang harus terpenuhi, sehingga kurang dalam memandang bagaimana hubungan atau pernikahan selanjutnya akan bahagia atau tidak. Sebagaimana yang dilaporkan dalam penelitian Marcus dan Winnie (2009) yang membahas tentang intensi menikah kembali pada duda di Cina yakni dipengaruhi oleh usia, kepercayaan, ketidakmammpuan untuk memenuhi kebutuhan seksual, dan ketidakpuasan dengan hidup menduda. Umumnya duda dengan kebutuhan seksul yang tidak terpenuhi tiga kali lebih mungkin untuk melakukan remarriage (Marcus \& Winnie, 2009).

Untuk dapat membangun rumah tangga kembali seseorang seharusnya memiliki relationship self-efficacy agar terjadi hubungan yang lebih baik dan pernikahan yang lebih baik dari sebelumnya. akan tetapi jika dilihat lebih lanjut, dalam penelitian ini pengaruh relationship self-efficacy secara keseluruhan memang memiliki pengaruh, namun pada proporsi varians sumbangan yang diberikan sangat kecil yakni 1,9\% dan tidak signifikan. Hal ini mungkin terjadi karena pengaruh budaya kawin cerai di Lombok Timur yang telah menjadi budaya internal sehingga orang memandang bahwa pernikahan kembali lumrah terjadi setelah perceraian. Selain itu jika dilihat dari faktor penyebab tingginya kawin cerai di Lombok Timur dalam penelitian Wahyudi (2004) tentang tradisi kawin cerai pada suku sasak pada perspektif hukum, mengatakan bahwa banyak faktor yang mempengaruhi meningkatnya kawin cerai di Lombok Timur salah satunya yakni adanya kebanggaan seseorang dengan pernikahan yang berkali-kali, dan ini biasanya 
berkembang pada masyarakat yang memiliki pendidikan rendah. Berdasarkan hasil pengamatan di lapangan juga memang terdapat 
beberapa responden (khususnya duda) yang menganggap pernikahan berkali-kali setelah perceraian itu adalah sebagai presetasi tersendiri. Jadi hal inilah yang mungkin juga menyebabkan relationship self-efficacy menyumbang proporsi varian yang sangat kecil dan tidak signifikan terutama pada responden laki-laki juga tidak berpengaruh sama sekali, karena orang tersebut cenderung tidak mempedulikan apa yang akan terjadi pada pernikahan selanjutnya baik akan bahagia atau tidak, asalkan kebutuhan seksual terpenuhi dan eksistensi pada masyarakat tentang presetasi menikah berkali-kali tersebut maka seseorang akan memiliki intensi untuk remarriage.

Variabel yang signifikan selanjutnya yakni variabel demografi jenis kelamin dan usia. Ada pengaruh yang signifikan terlihat pada variabel jenis kelamun dan memberikan sumbangan sebesar 5\%. Laki-laki memiliki intensi untuk menikah kembali lebih tingi daripada perempuan. Perbedaan intensi ini mungkin terjadi karena laki-laki cenderung lebih membutuhkan pendamping hidup sebagai pelipur lara dalam hidupnya, sedangkan perempuan selain masalah image janda yang negatif pada orang timur, usia, ekonomi, dan kejelasan nasib anak, wanita juga cenderung lebih lama dalam proses healing pasca perceraian. Dalam Hurlock (1980) juga dikatakan bahwa laki-laki yang bercerai relatif lebih mudah untuk dapat men ikah kembali daripada wanita.

Di Cina hasil penelitian dari Marcus dan Winnie (2009) pada penjelasan sebelumnya mengatakan bahwa intensi remarriage pada duda secara signifikan dipengaruhi juga oleh usia. Pada penelitian inipun sama, intensi remarriage dipengaruhi juga oleh faktor usia. Di mana usia memberi pengaruh yang negatif signifikan terhadap intensi remarriage di Lombok Timur, artinya semakin tinggi usia semakin rendah keinginan untuk menikag kembali, sebaliknya semakin rendah usia seseorang semakin tinggi keinginan untuk menikah kembali.

Perceived behavior control memiliki pengaruh yang tidak signifikan terhadap intensi remarriage janda dan duda di Lombok Timur. Hal ini tidak sejalan dengan teori intensi theory of planned behavior yang mengatakan bahwa seseorang memiliki intensi untuk mewujudkan perilaku yakni ketika mereka menilai positif, ketika mereka mengalami desakan sosial untuk mewujudkannya, dan ketika mereka percaya bahwa mereka memiliki maksud dan kesempatan untuk melakukannya (Ajzen, 2005). Padahal dalam penelitian Armitage dan Conner (2001) mengungkapkan PBC memiliki korelasi berganda terhadap intensi dan perilaku. Namun pada 
penelitian ini hanya berlaku konsep dari teori intensi klasik yakni theory of reasoned action (Fishbein \& Ajzen, 1975) yang mengatakan bahwa seorang akan berintensi jika ada pengaruh yang berasal dari faktor personal (sikap terhadap perilaku) dan faktor pengaruh lingkungan (norma subjektif). Prinsip dari teori ini adalah jika perilaku tersebut sepenuhnya di bawah kendali atau kemauan individu, meski ia sangat termotivasi oleh sikap dan norma subjektifnya, ia mungkin tidak akan secara nyata menampilkan perilaku tersebut, karena theory of reasoned action cukup berhasil jika diaplikasikan pada perikaku yang di bawah kendali diri sendiri (Achmat, 2010).

\section{DAFTAR PUSTAKA}

Achmat, Z. (2010). Theory of planned behavior: Masihkah relevan? Diambil pada tanggal 12 Februari 2013 dari zakaria.staff.umm.ac.id.

Ajzen, I. \& Fishbein, M. (1975) Belief, attitude, intention and behavior: An introduction to theory and research. USA: Addison Wesley Publishing Company.

Ajzen, I. (1991). The theory of planned behavior. Organizational Behavior and Human Decision Processes (50), 179-211.

Antaramataram.com (2011). BPPKB NTB dorong perkawinan sesuai usia dianjurkan. Diambil pada tanggal 20 Oktober, 2011 dari www.NTBOnline.com.

Anwar, K. 2011. Dekati persoalan hulu; Kawin-cerai di Lombok. Kolom teropong budaya. Koran Kompas, hal. 39.

Armitage, C. J. \& Conner, M. (2001). Efficacy of the theory of planned behavior: A meta-analytic review. Journal of Social Psychology, (40), 471-49.

Azwar, S. (1995). Sikap manusia teori dan pengukurannya. Yogyakarta: Pustaka Pelajar.

Bandura, A. (1977). Self-efficacy: toward a unifying theory of behavioral change. Psychological Review, 84 (2). 191-215.

Bolang, A. D. B. (2012). Perbedaan psychological well-being orang tua tunggal laki-laki dan orang tua tunggal perempuan yang bercerai. Tugas UAS-STS Fakultas Psikologi Universitas Esa Unggul.

Buehlman, K. T, Gottman, J. M. \& Katz, L. F. (1992). How a couple views their past predicts their future: predicting divorce from an oral history interview. Journal of Family Psyhcology, 34 (5). 295-318.

Chiu, Marcus Y. L. \& Ho, Winnie W. N. (2010). Intent to remarry among Chinese elderly widowers: An oasis or an abyss? American Journal of Men's Health, 4 (3) 258-266. 
Cinamon, R. G. (2006). Anticipated work-family conflict: Effects of gender, self-efficacy, and family background. The National Career Development Association.

Dewi, D. K. (2009). Penyesuaian diri pada wanita dewasa muda pasca bercerai. Skripsi Fakultas Psikologi Universitas Gunadarma.

Fincham, F. D. (2000). The longitudinal association between attributions and marital satisfaction: Direction of effects and role of efficacy expectations. Journal of Family Psychology, 14 (2), 267-285.

Francis, J. J. (2004). Constructing questionnaire based on the theory of planned behavior: A manual for health services researchers. United Kingdom: Quality of life and management of living resources.

Frank, G., Plunkett, S. W., \& Otten, M. P. (2010). Perceived parenting, selfesteem, and general self-efficacy of Iranian American adolescents. (19): 738-746.

Hendarmini, Y. (2004). Pengambilan keputusan pada janda cerai untuk menikah kembali. Skripsi Fakultas Psikologi. Universitas Indonesia.

Hurlock, E. B. (1980). Psikologi perkembangan: suatu pendekatan sepanjang rentang kehidupan $\left(5^{\text {th }} e\right.$ d). Jakarta: Erlangga.

Kahn, S. (2007). Factors influencing intentions to marry: A comparison of Americans and Australians. UW-L Journal of Undergraduate Research $X$

Nisa, Fashihatin. (2009). Penyesuaian perceraian pada wanita desa yang bercerai. Skripsi Fakultas Psikologi Universitas Sumatera Utara.

NN. (2012). Data statistik perkara tahun 2012 pengadilan tinggi agama Mataram. Diambil pada tanggal 11 Februari 2012. http://ptamataram.go.id/informasi-perkara/statistik-perkara.

Olson, David H. \& DeFrain, Jhon. (2006). Marriage and family intimacy, diversity, and strengths $\left(5^{\text {th }}\right.$ ed). USA: McGraw Hill.

Park, S. S. (2012). The development of the marital attitudes and expectations scale. Thesis. Department of Psychology: Coloradi State University.

Pradnyamita, R. (2006). Merajut benang pernikahan Islami. Diambil pada tanggal 12 Februari 2013. http://www.ummusalma.wordpress.com.

Segrin, C. \& Flora, L. (2005). Family communication. USA: Lawrence Erlbaum Associates.

Syafruddin \& Ismail. (1997). Laporan penelitian: perceraian pada masyarakat pedesaan Lombok Nusa Tenggara Barat. Fakultas Keguruan dan Ilmu Pendidikan. Universitas Mataram.

Syafruddin \& Ismail (2000). Laporan penelitian: tradisi kawin cerai (studi pola hubungan kekuasaan pria-wanita dalam perceraian di masyarakat pedesaan Lombok Nusa Tenggara Barat. Fakultar Keguruan dan Ilmu Pendidikan. Universitas Mataram. 
Vennum, A. \& Fincham, F. D. (2011). Assessing decision making in young adult romantic relationships. Psychological Assessment (in press). Diambil pada tanggal 16 April 2013 http://www.apa.org/pubs/journals/pas/index.aspx

Wahyudi, H. (2004). Tradisi kawin cerai pada masyarakat suku Sasak Lombok serta akibat hukum yang ditimbulka: studi di Kecamatan Pringgabaya Kabupatan Lombok Timur. Tesis. Universitas Diponegoro Semarang.

Zuhdi, H. (2011). Lombok mirah sasak adi. Jakarta: Imsak Press. 


\title{
PENINGKATAN PSIKOLOGI BELAJAR BAHASA INGGRIS MELALUI MATERI BACAAN OTENTIK
}

\author{
Nu rul Handayani \\ UIN Syarif Hidayatullah Jakarta \\ hannurulyani@gmail.com
}

\begin{abstract}
This study is an action research focused goal to get the information to ensure that the ability of students in the psychology of learning English can really be imporved through the use of authentic reading materials as a teaching material and by giving students assignments in learning process. As an action research study is qualitative and the emphasis is on the process and the outcome. The researcher, who is also a teacher who has an interest, directly plan dan carry out research with a clear goal and strategy is to look for a more effective approach to learning. This study was conducted in two cycles, each cycle includes four classroom sessions and four independent learning tasks as well as measures of planning, action, abservation and reflection and evaluation tests. Overall, the study was run for two months from March 7 to May 9 2012. From the observations made by the researcher or by the collaborators and the impression of the students study subjects, it can be concluded that the strategy is the use of authentic reading materials can be implemented either as an effective approach to learning. By comparing the average of the beginning and end of the test scores shows that there has been an increase in the ability to read for comprehension. Comparison of the average value is 41.7 compared to 83.2. by comparing the values broken down by type of linguistic ability, it looks very significant improvement of any type that have tested the ability of the language. Changes in non-lingustic areas mainly in the aspects of motivation and confidence.
\end{abstract}

Keywords: Psychology Of Learning, Authentic Materials And Learning Outcomes

\begin{abstract}
Abstrak
Penelitian dilakukan dalam bentuk action research (penelitian tindakan) dengan fokus tujuan untuk mendapatkan informasi untuk menguji apakah kemampuan siswa dalam psikologi belajar bahasa Inggris benar-benar bisa ditingkatkan melalui penggunaan bahan bacaan otentik sebagai bahan belajar dan memberikan tugas kepada siswa dalam proses pembelajaran. Action research merupakan penelitian kualitatif yang menekankan pada proses dan hasil. Peneliti yang juga merupakan seorang guru secara langsung membuat perencanaan dan melaksanakan penelitian dengan tujuan yang jelas, yakni menemukan pendekatan belejar yang lebih efektif. Penelitian ini dilaksanakan dalam dua seri, masingmasing seri melibatkan empat sesi kelas dan empat tugas belajar mandiri yang mengukur planning, action, observation dan reflection and evaluation test. Secara keseluruhan, penelitian ini dilaksanakan selama dua bulan yakni pada 7 Maret sampai dengan 9 Mei 2012. Berdasarkan observasi yang dilakukan oleh tim peneliti, dan berdasarkan pada impresi siswa terhadap subjek pembelajaran, dapat disimpulkan bahwa strategi penggunaan bahan bacaan otentik dapat diimplementasikan sebagai pendakatan belajar yang efektif.
\end{abstract}




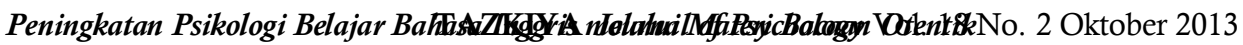

Perbandingan rata-rata nilai awal dan nilai akhir menunjukkan adanya peningkatan kemampuan dalam pemahaman bacaan. Perbandingan nilai rata-rata keduanya adalah 
sebesar 41.7 dan 83.2. Dengan membandingkan nilai berdasarkan tipe kemampuan linguistik, tampak adanya peningkatan yang signifikan pada setiap jenis uji kemampuan bahasa. Perubahan dalam arena non-linguistik terutama pada aspek motivasi dan rasa percaya diri.

Kata Kunci: Psikologi Belajar, Materi Otentik, Hasil Pembelajaran

Diterima: 11 Mei 2013 Direvisi: 4 Juni 2013 Disetujui: 12 Juni 2013

\section{PENDAHULUAN}

Di Indonesia, bahasa inggris berfungsi sebagai bahasa asing yang wajib dipelajari pada tingkat sekolah menengah sampai perguruan tinggi termasuk di Perguruan Tinggi Agama Islam. Di Perguruan Tinggi Agama Islam khususnya di Fakultas Syariah dan Hukum UIN Jakarta bahasa Inggris diajarkan untuk tujuan agar mahasiswa mampu memahami bahan bacaan bahasa Inggris baik yang bersumber dari buku teks ataupun media tulis lainnya. Oleh sebab itu, mahasiswa Fakultas Syariah dan Hukum UIN Jakarta harus mampu memahami bacaan bahasa Inggris.

Akan tetapi pada kenyataannya mahasiswa masih mengalami masalah dalam memahami bacaan bahasa Inggris. Hal ini dapat dibuktikan dari berbagai fenomena yang terjadi di lapangan. Mahasiswa sering salah memahami bacaan, kurang mampu menentukan mana pokok pikiran dan mana penjelas di dalam paragraf dan bahkan walaupun semua arti kata bahasa inggris sudah diketahui, mahasiswa belum juga dapat menentukan isi bacaan dengan baik.

Bukti lain dapat dilihat dari nilai bahsa Inggris yang diperoleh mahasiswa belum begitu memuaskan. Target yang harus dicapai oleh mahasiswa salam menguasai mata kuliah bahasa Inggris seharusnya $80 \%$ tetapi realitasnya penguasaan mahasiswa masih di bawah target itu.

Untuk mengatasi masalah di atas sudah banyak usaha yang telah dilakukan antara lain dosen sudah melakukan berbagai upaya untuk menyiapkan bahan bacaan yang mudah dipahami dan relevan dengan kebutuhan mahasiswa. Universitas telah melakukan pelatihan untuk dosendosen bahasa Inggris, membuat seminar tentang peningkatan kemampuan mengajar dosen, dan sebagainya. Namun upaya-upaya ini belum dapat meningkatkan kemampuan bahasa Inggris mahasiswa khususnya dalam meningkatkan pemahaman bacaan.

Bacaan otentik adalah bacaan-bacaan yang berasal dari koran-koran 
atau majalah-majalah asing lainnya. Dengan memahami bahan bacaan ini, mahasiswa terbantu dalam menulis bahan belajar yang memiliki wawasan lebih luas. Apalagi sebagian besar mahasiswa yang merupakan calon hakim 
agama dan ahli ekonomi syariah harus mampu mendapatkan informasi aktual dari bacaan otentik. Dengan demikian ia akan memahami realitas sosial yang sedang terjadi di masyarakat.

Fokus masalah dalam bahan penelitian ini adalah peningkatan psikologi belajar bahasa Inggris melalui materi bacaan otentik, pada mahasiswa UIN Jakarta di Fakuktas Syariah dan Hukum UIN Jakarta.

\section{Hakikat Psikologi Belajar}

Bagi seorang dosen, yang tugas utamanya adalah mengajar, sangat penting memahami psikologi belajar. Kegiatan pembelajaran, termasuk pembelajaran Bahasa Inggris, sarat dengan muatan psikologis mengabaikan aspek-aspek psikologis dalam proses pembelajaran akan berakibat kegagalan, sehingga tujuan pembelajaran tidak tercapai.

Tidak dapat dipungkiri lagi bahwa antara proses perkembangan dengan proses belajar mengajar memiliki keterkaitan. Sehubungan dengan ini, setiap dosen di perguruan tinggi selayaknya memahami seluruh proses dan perkembangan manusia, khususnya mahasiswa. Pengetahuan mengenai proses dan perkembangan dan segala aspeknya itu sangat bermanfaat, antara lain (Muhibbi, 1991):

1. Dosen dapat memberikan layanan dan bantuan dan bimbingan yang tepat kepada mahasiswa dengan pendekatan yang relevan dengan tingkat perkambangannya.

2. Dosen dapat mengantisipasi kemungkinan-kemungkinan timbulnya kesulitan belajar mahasiswa tertentu.

3. Dosen dapat memertimbnagkan waktu yang tepat dalam memulai aktifitas proses belajar mengajar bidang studi tertentu, dosen dapat menemukan dan menetapkan tujuan-tujuan pengajaran sesuai dengan kemampuan psikologisnya.

Dari beberapa peranan psikologi belajar, dapat kita khususkan sebagai berikut:

1. Psikologi belajar memiliki peranan penting dalam membantu mempersipakan dosen atau calon dosen yang professional.

2. Pengetahuan tentang psikologi belajar diharapkan mampu membantu memecahkan permasalahan mahasiswa dalam belajar.

3. Pengetahuan tentang psikologi belajar memudahkan penerapan pengetahuan, pendekatan dan komunikasi kepada mahasiswa didik.

4. Pengetahuan tentang psikologi belajar membantu menciptakan suasana edukatif dan efektif.

Bacaan Otentik

Kata Authentik bisa dipadankan sebagai genuine, undisputed origin, sedang 
bacaan adalah segala bahasa tulisan yang dibaca untuk dipahami isinya.

Bacaan disini tentu bisa berwujud suatu wacana tulis, karangan, atau 
discourse, atau cuplikan karangan, atau passage yang terdiri dari beberapa paragraf tetapi termasuk juga tulisan pendek berisi petunjuk di tempat- tempat umum seperti Baggage Claim, toilet, dan lain-lain. Juga bisa berwujud jadwal, daftar menu, pengumuman, iklan dan lain-lain.

Pengenalan teks bahasa inggris yang otentik membawa beberapa keuntungan, yaitu pertama; memberi motivasi, karena siswa akan benarbenar mendapat nilai kegunaan praktis dari bahasa Inggris yang dipelajarinya. Kedua; memupuk rasa percaya diri karena mereka merasa benar-benar bisa menggunakan bahasa Inggris.

Sejalan dengan ini Michael Lewis dan Jimmie Hill mengatakan: "If students are really going to use their English outside the classroom they will need to be able to handle many diffirent types of text such as menus, instructions, sign, information, stories, letters, advertisements, hand-written notes, not only those specially prepared for languange taching textbooks, because each of this types of text is different from the others in purpose and also in structure and language" (Michael, 1985).

Tentang bahan otentik yang berupa petunjuk, di Jakarta pun mahasiswa akan banyak menemuinya, seperti papan nama, money changer, theatre, toilet, arrival, departure, no parking, dan sebagainya. Tentang teks yang lebih panjang seperti iklan, pengumuman, tidak saja dapat ditemui pada majalah dan koran bahasa Inggris. Koran bahasa indonesia seperti Kompas pun hampir selalu memuat iklan dalam bahasa Inggris. Terjemahan ayat al- qur'an dalam bahasa Inggris seperti Thee do we worship and thine aid we seek (The Holy Qur'an, 1410 Hijriah). Meskipun termasuk bahasa Inggris tinggi, karena beberapa mahasiswa hafal betul ayat aslinya dan terjemanhannya dalam bahasa Indonesia, mereka mudah memahami kalimat bahasa inggris ini dan menambah kebanggaan untuk mampu mengucapkan sebagai bumbu dalam percakapan mereka.

\section{Riset Aksi}

Menurut Kemmis dan Mc Taggart (1990) riset aksi merupakan suatu kegiatan refleksi diri kolektif yang dilakukan oleh para peserta dalam situasi sosial guna meningkatkan rasionalitas dan penilaian mereka terhadap praktikpraktik sosial atau pendidikan sesuai dengan tuntutan mereka tentang kondisi dan situasi di mana praktik dilakukan.

Dari beberapa pengertian di atas, riset aksi dapat diartikan sebagai suatu pendekatan untuk memperbaiki pendidikan melalui perubahanperubahan dengan cara mendorong para pengajar untuk memikirkan praktik pengajaran yang dilakukannya sendiri dan agar pengajar menjadi kritis terhadap praktik mengajarnya dan punya keinginan untuk melakukan perubahan ke arah yang lebih baik. 


\section{METODE}

\section{Metode dan Disain Intervensi/Tindakan Rancangan Siklus Penelitian}

Penelitian ini menggunakan metode riset aksi yakni suatu penelitian campuran antara kualitatif dan kuantitatif (eksperimen). Langkah-langkah yang akan digunakan dalam riset aksi ini adalah langkah-langkah Kemmis dan Mc Taggart (1990) yang meliputi: planning, action, observing, dan reflecting. Dalam penelitian ini perencanaan didasari oleh masalah-masalah yang ditemukan untuk digunakan dalam implementasi. Kegiatan (action) tersebut digunakan untuk mencari pemecahan masalah. Dalam mengimplementasikan suatu perencanaan, kegiatan tidak selalu sesuai dengan apa yang telah direncanakan.

Langkah berikutnya dalah observasi atau pemantauan terhadap proses, pengaruh dan hasil apa saja yang diperoleh dalam kegiatan tersebut. Sedangkan dalam mengadakan refleksi seharusnya dijadikan bahan pertimbangan terhadap proses kegiatan tersebut dan menganalisis masalah baru yang mungkin timbul. Setelah keempat langkah diambil peneliti masih merasakan perlu adanya diskusi dengan para kolaborator untuk mengadakan evaluasi terhadap hasil kegiatan tersebut dan merencanakan kembali untuk membuat rencana berikutnya.

\section{Partisipan Penelitian}

Data yang akan diambil nerasal dari mahasiswa reguler semester dua angkatan tahun 2012/2013 yang mengikuti mata kuliah bahasa Inggris II yang berjumlah sekitar 19 orang laki-laki dan 24 orang perempuan, sehingga keseluruhannya adalah 43 orang. namun dalam penelitian ini subjek penelitian diambil 20 orang yang dipilih secara acak yaitu dengan pencabutan lotre nomor urut. Di samping itu data diambil juga dari hasil diskusi dengan para kolaborator.

\section{Peran dan Posisi Peneliti dalam Penelitian}

Peran dan posisi peneliti dalam penelitian adalah selain sebagai penggerak tindakan penelitian sekaligus sebagai pelaku penelitian ini dimana peneliti sebagi guru merupakan fasilitator belajar siswa dan mengamati proses pembelajaran mulai dari awal sampai akhir. Dalam penelitian ini peneliti melakukan langkah tindakan sebagai terapi pembelejran demi tercapainya perbaikan dan hasil yang lebih baik, dimana tindakan dimulai dari perencanaan, tindakan, observasi sampai refleksi.

Siklus1 (Satu)

1. Perencanaan Tindakan 
Sebelum melaksanakan rencana penelitian yang diadakan untuk mahasiswa fakultas syariah dan hukum UIN Jakarta ini, peneliti bersama-sama para kolaborator berusaha berdiskusi mengenai: 
a. Membuat skenario suatu model atau bentuk proses belajar mengajar berdasarkan kaji tindakan yang tidak menyimpang dari tujuan instruksional.

b. Mempersipakan sarana dan fasilitas pendukung.

c. Menyediakan dan menyusun alat evaluasi.

2. Pelaksanaan Tindakan

Pertama, dengan berencana untuk membagi satu kelas menjadi beberapa kelompok, di mana masing-masing kelompok terdiri dari 5 mahasiswa dan penulis meminta setiap kelompok untuk mencari dan mengumpulkan sebuah artikel bacaan-bacaan otentik bahasa inggris yang dapat mereka ambil dari koran-koran atau majalah-majalah yang menggunakan bahasa inggris.

Kedua, peneliti akan mengambil tiga materi bacaan otentik bahasa Inggris yang telah terkumpul secara acak (random) dan memberikan tugas secara mandiri yang harus dikerjakan di luar jam perkuliahan kepada para mahasiswa untuk memahami bacaan tersebut. Bila menemukan kosakata-kosakata baru agar dicatat dan dicari padanan katanya dalam bahasa Indonesia, demikian juga tata bahasa yang ada dalam teks bacaan tersebut.

Ketiga, peneliti menyanyakan hasil apa saja yang diperoleh selama belajar mandiri tersebut di kelas dan menugaskan para mahasiswa untuk menjawab pertanyaan-pertanyaan yang telah peneliti siapkan sebelumnya.

3. Observasi

Observasi juga dilakukan terhadap seberapa jauh tindakan yang dilakukan membantu mencapai tujuan seperti yang direncanakan, terutama tentang kemampuan siswa dalam pemahaman memahami bacaan otentik bahasa Inggris dan kemampuan guru dalam mengelola proses pembelajaran.

4. Refleksi (Hasil)

Tahap refleksi dilakukan untuk melakukan penilaian terhadap proses yang terjadi, masalah yang muncul, dan segala hal yang berkaitan dengan tindakan yang telah dilakukan berdasarkan hasil observasi. Dimana semua hasil observasi dan temuan-temuan tersebut akan dibahas dan didiskusikan para pihak yang terkait yaitu peneliti dan kolaborator untuk mengevaluasi hasil tindakan dan merumuskan perencanaan berikutnya.

Siklus 2 (Dua)

Apabila masih diperlukan, proses diulang lagi. Dimana persiapan dan pelaksanaan siklus kedua berdasarkan refleksi siklus pertama, langkahlangkahnya akan mengikuti siklus pertama atau berupa revisi rancangan pertama. 
Siklus 3 (Tiga) 
Apabila masih dipandang perlu, maka siklus ketiga tetap dilaksanakan.

\section{Hasil Intervensi Tindakan yang Diharapkan}

Berdasarkan penelitian yang mengacu pada penelitian tindakan ini atau action research maka akan didapati suatu hipotesa bahwa model pembelajaran reading otentik bahasa Inggris melalui belajar mandiri dapat meningkatkan kreativitas siswa dalam memahami bacaan bahasa Inggris.

\section{Instrumen-instrumen Pengumpul Data yang Digunakan}

Instrumen pengumpul data terdiri dari lembar tes, catatan lapangan, lembar pedoman wawancara, dokumen siswa serta alat penilaian kemampuan siswa.

\section{Teknik Pengumpulan Data}

Teknik pengumpulan data yang dilaksanakan dalam penelitian in mengacu pada paradigma penelitian kualitatif. Di mana data dikumpulkan sejak dari awal penelitian sampai penelitian berakhir dan kegiatan ini dilakukan selama dua kali di dalam satu semester yaitu selama semester dua.

\section{Hasil Tes Pemahaman Bacaan}

Data yang terkumpul adalah hasil tes pemahaman wacana bacaan otentik sedangkan wacana yang dijadikan tes adalah wacana yang direncanakan dalam perkuliahan mengenai wacana otentik, sehingga ruang lingkup wacana tidak melampaui satuan perkuliahaan yang telah direncanakan. Bentuk tes yang dipergunakan juga cukup beragam dengan tingkat kesukaran yang disesuaikan dengan kondisi mahasiswa yang mempunyai latar blekang berbeda.

\section{Hasil Kolaborasi}

Sesuai dengan prinsip ketiga riset aksi yaotu prinsip kolaboratif, dalam riset aksi ini upaya kolaboratif juga dilaksanakan. Kolaborator adalah dua orang pengajar sejawat senior peneliti, proses kolaborator dilakukan pada saat pembelajaran dan kasil kolaborasi dibicarakan dan didiskusikan dengan peneliti segera setelah pembelajaran berakhir. Dengan demikian kolaborator dilakukan melalui kehadiran langsung. Sekalipun pernah terjadi kolaborator dilakukan dengan menonton hasil rekaman foto, hal itu terjadi karena kolaborator berhalanagan hadir pada saat pembelajaran, namun hasil kolaborasi oleh kolaborator bersangkutan juga langsung didiskusikan dan upaya perbaikan pembelajaran juga dilaksanakan peneliti. 


\section{Tindak Lanjut/Pengembangan Perencanaan Tindakan Perencana}

Sebagaimana telah diutarakan langkah pembelajaran psikologi belajar bahasa Inggris wacana bacaan otentik, berikut perencanaan langkahlangkah tersebut:

\section{Langkah 1 (Langkah Persiapan)}

Untuk memahami wacana, mahasiswa perlu dipersiapkan agar proses pemahamannya lebih berhasil guna. Langkah persiapan ini dapat dilakukan dengan: Panggilan Schemata, yaitu pemberian pertanyaan-pertanyaan yang dapat menggungah pengetahuan pembaca. Pertanyaan dan pernyataan selain untuk menggugah pengetahuan, juga agar mahasiswa dapat mengartikan pengetahuannya pada tema wacana yang adakan dibahas. Caranya yaitu dengan membuat gambar asosiasi atau assosiogram di papan tulis. Tema wacana yang berbentuk kata kunci pokok dituliskan di tengah papan tulis dengan dilingkari dan kemudian melalu pertanyaan-pertanyaan, wacana yang berbentuk kata kunci pokok tersebut diuraikan lagi melalui pengetahuan mahasiswa seputar tema, yang dituliskan di sekeliling tema atau kata kunci pokok.

\section{Langkah 2 (Membaca Wacana)}

Pada langkah kedua, mahasiswa baisanya diminta untuk membaca wacaan, variasi membaca dapat dilkaukan dengan mula-mula membaca secara mandiri tanpa bersuara kemudian membaca bersuara dengan membaca dengan bergantian.

\section{Langkah 3}

Setelah kegiatan membaca, maka tekni yang akan diterapkan adalah untuk mengecek pemahaman mahasiswa tentang hal-hal yang faktual, seperti psikologi belajar bahasa Inggris yang berhubungan dengan waktu, tempat, dan pelaku dalam teks bacaan. Untuk itu sosialisasi kerja yang diterapkan adalah menjawab pertanyaan baik secara lisan maupun secara tertulis.

\section{Langkah 4}

Setelah pemahaman faktual diperoleh mahasiswa, langkah berikut adalah pemahaman secara global dan detil, pemahaman tentang bentuk pertanyaan inferensi dan pemahaman yang mneuntut respon non kebahasaaan. Pemerolehan ini selain dilakukan dengan memberikan pertanyaan yang membutuhkan jawaban secara detil, inferensi juga mnuntut adanya respon non kebahasaan.

\section{Langkah 5}

Pada langkah kelima, mahasiswa akan mengerjakan latihan mandiri secara tertulis. Pengukuran keberhasilan adalah kemampuan mahasiswa dalam 
menjawab berbagai bentuk pertanyaan yang berhubungan dengan pemahaman bacaan yang sesuai dengan indikator yang telah ditentukan.

Sedangkan selanjutnya mahasiswa mendapat perlakuan yang diawali psikologi belajar bahasa Inggris dengan bantuan kamus, maka setelah langkah keempat yaitu pemahaman detil, global, inferensi dan respon non linguistik dilakukan. Pada langkah kelima ini pemahaman mahasiswa akan dipantau melalui penerapan Assoziogramm. Hal ini dilkaukan karena melalui Assoziogramm mahasiswa diharapkan akan dapat memahami bacaan tersebut dengan baik.

\section{HASIL}

\section{Kondisi Awal Psikologi Belajar Bahasa Inggris Mahasiswa}

Untuk mendapatkan kondisi awal mahasiswa dalam psikologi belajar bahasa Inggris bacaan bahasa Inggris mahasiswa dilakukan kegiatan berikut: mahasiswa diberi wacana tulis di mana wacana tersebut belum dikenal mahasiswa dan belum pernah dibahas di kelas. Bersamaan dengan pemberian wacana, mahasiswa juga diberi pertanyaan tertulis tentang wacana itu. pertanyaan tersebut diberikan dengan maksud mendapatkan data untuk dianalisis.

Pertanyaan yang disusun menurut Francoise Grelled tentang cara mengembangkan kemampuan membaca yakni pertanyaan yang mengukur faktor kebahasaan, yaitu : (1) pemahaman tentang pertanyaan faktual (scanning), (2) pemahaman tentang informasi global (skimming), (3) inferensi, (4) non linguistic respon.

Adapun hasil psikologi belajar bahasa Inggris bacaan otentik bahasa Inggris pada mahasiswa dapat terlihat dalam tabel berikut ini.

Tabel 2

Kondisi Awal Faktor Kebahasaan

\begin{tabular}{ccccc}
\hline Kode Mahasiswa & $\mathbf{1}$ & $\mathbf{2}$ & $\mathbf{3}$ & $\mathbf{4}$ \\
\hline M 1 & 20 & 0 & 5 & 5 \\
M 2 & 10 & 10 & 10 & 20 \\
M 3 & 10 & 16 & 10 & 10 \\
M 4 & 5 & 13 & 10 & 15 \\
M 5 & 10 & 12 & 10 & 20 \\
M 6 & 15 & 10 & 5 & 10 \\
M 7 & 10 & 6 & 5 & 5 \\
M 8 & 15 & 18 & 0 & 5 \\
M 9 & 20 & 15 & 20 & 15 \\
M 10 & 10 & 12 & 10 & 10 \\
M 11 & 5 & 10 & 0 & 15 \\
M 12 & 10 & 10 & 10 & 20 \\
M 13 & 10 & 12 & 10 & 10
\end{tabular}




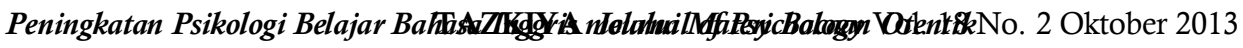

M 14

5

5

10

10 


\begin{tabular}{ccccc}
\hline Kode Mahasiswa & $\mathbf{1}$ & $\mathbf{2}$ & $\mathbf{3}$ & $\mathbf{4}$ \\
\hline M 15 & 10 & 5 & 10 & 10 \\
M 16 & 5 & 10 & 0 & 25 \\
M 17 & 5 & 0 & 5 & 10 \\
M 18 & 10 & 10 & 5 & 15 \\
M 19 & 10 & 5 & 10 & 15 \\
M 20 & 10 & 20 & 20 & 20 \\
\hline
\end{tabular}

Keterangan : M1-M20 = Nama Mahasiswa

Penilaian $1=$ Pertanyaan Scanning

Penilaian 2 = Pertanyaan Skimming

Penilaian $3=$ Pertanyaan Inferensi

Penilaian $4=$ Pertanyaan Non Linguistik Respon

Setelah dilkaukan tes awal maka dapat dilihat kondisi awal psikologi belajar bahasa Inggris wacana bahasa Inggris mahasiswa, melalui hasil tes membaca yang diperoleh mahasiswa. Dan berdasarkan data di atas terlihat dengan jelas bahwa diantara 20 mahasiswa hanya ada 2 mahasiswa yang dinilainya di atas 50 sedangkan lainnya bahkan masih di bawah nilai 50 . Dari beberapa jenis pertanyaan dapat terlihat bahwa para mahasiswa sangat rendah penguasaan pemahamannya dalam jenis pertanyaan scanning, skimming, inferensi dan non linguistik respon hampir semua mahasiswa yang tidak dapat menjawab pertanyaan tersebut dengan sempurna. Terlihat dengan jelas bahwa dalam bentuk pertanyaan scanning (pertanyaan faktual) dimana mahasiswa dituntut dapat menjawab pertanyaan dengan hanya membaca teks secara sekilas saja, tidak ada satupun mahasiswa yang dapat menjawab dengan sempurna dan hanya ada 2 orang mahasiswa yang mendekati sempurna yaitu M1 dan M9.

Dari hasil tes pemahaman dalam bentuk skimming (pertanyaan yang menuntut mahasiswa dapat menemukan informasi secara detil dan global) dapat terlihat dalam tabel di atas bahwa pemahaman mereka sangat rendah, bahkan ada beberapa mahasiswa seperti M1 dan M17 yang sama sekali tidak dapat menajwab pertanyaan tersebut. Dari jenis pertanyaan inferensi (pertanyaan tentang kosakata) juga terlihat ada 3 orang mahasiswa yaitu M8, M11 dan M16 yang mendapat nilai 0 dan tidak ada satu orang pun yang mendapat nilai sempurna (benar semua). Sedangkan dalam bentuk pertanyaan non linguistik respon yaitu bentuk pertanyaan yang menuntut kemampuan verbal, hanya ada satu mahasiswa yang dapat menjawab dengan sempurna yaitu M16.

Dan secara keseluruhan hasil tes tersebut memeperlihatkan bahwa nilai rata-rata adalah sebesar 41,7 (hasil terlampir). Hal ini berati bahwa psikologi belajar bahasa Inggris mahasiswa masih tergolong rendah jika dibanding dengan target penguasaan yang harus dicapai sebesar $80 \%$. Atas 
dasar ini, perlu dilakukan perbaikan terhadap psikologi belajar bahasa Inggris mahasiswa khususnya untuk wacana bacaan bahasa Inggris. 


\section{Identifikasi Ide-Ide Perbaikan}

Berdasarkan kondisi awal di atas dapat dilihat bahwa kemampaun mahasiswa dalam psikologi belajar bahasa Inggris wacana bahasa Inggris masih dalam kategori beoum sesuai harapan. Hal ini disebabkan oleh berbagai faktor, baik faktor internal maupun eksternal.

Dari faktor internal, kemampuan sebagian besar mahasiswa kurang memuaskan. Kemungkinan penyebanya adalah kurang siapnya mahasiswa mengerjakan tes yang diberikan. Mahasiswa kurang memahami bacaan secara komprehensif, belum mengetahui strategi membaca yang efektif, tidak memiliki kamus, lemahnya penguasaan kosakata dan struktur, lambat dalam membaca dan lain-lain.

Dari faktor eksternal dapat dilihat bahwa ada kemungkinan kemampuan disen mengajar belum maksimal, pendekatan yang digunakan kurang tepat, materi yang diberikan belum mengahyati kebutuhan mahasiswa dan sebagainya.

Di samping faktor yang disebutkan di atas, banyak lagi faktor lain yang menyebabkan lemahnya kemampuan membaca mahasiswa. Namun untuk menyusun program perbaikan, penelitian ini dibatasi pada usaha peningkatan psikologi belajar bahasa Inggris melalui bacaan-bacaan otentik, strategi dalam meningkatkan pemahaman membaca, dan materi perkuliahan.

\section{Alternatif Pemecahan Masalah}

Untuk memecahkan masalah rendahnya psikologi belajar bahasa Inggris wacana otentik bahasa Inggris di atas perlu dilakukan usaha-usaha yang tepat. Usaha-usaha tersebut dapat dilkaukan melalui verifikasi kuasi eksperimen, pengembangan model pembelajaran, disertai penelitian tindakan di dalam kelas.

\section{Perencanaan dan Observasi}

Program aksi yang akan diimplementasilan perlu direncanakan terlebih dahulu. Perencanaan program aksi tersebut terdiri dari beberapa siklus atau aksi yang dilengkapi dengan langkah-langkah yang menunjang peningkatan psikologi belajar bahasa Inggris. Adapun langkah-langkah dalam setiap siklus tersebut adalah:

1. Pre Reading

Pada langkah ini, dosen melakukan brainstorming untuk menggali skemata dengan memberi pertanyaan atau pernyataan yang menggugah pengetahuan mahasiswa. Pertanyaan dan pernyataan ini juga berperan agar mahasiswa dapat mengaitkan pengetahuannya pada tema wacana yang akan dibahas.

2. While Reading 
Pada langkah ini, dosen membagi mahasiswa ke dalam kelompok yang masing-masing terdiri dari 5 orang. Bahan bacaan yang telah diambil secara random diberikan kepada setiap kelompok. Setiap kelompok mendapatkan satu bahan bacaan. Kemudian, dosen menyuruh kelompok membagi tugas untuk dikerjakan secaramandiri di rumah tentang bahan bahan bacaan otentik yang diberikan tadi. Selanjutnya dosen menugaskan mahasiswa mencari kosakata yang sulit, kalimat, paragraf dan memahami seluruh bacaan secara mandiri di rumah.

3. Post Reading

Untuk langkah ini, mahasiswa beserta dosen bertukar informasi tentang hasil bacaan mahasiswa yang dilakukan secara mandiri di rumah. Selain itu, dosen menanyakan kesulitan yang dihadapi mahasiswa dalam memahami bacaan dan memeriksa pemahaman mahasiswa terhadap bahan bacaan tersebut, kemudian untuk melihat pemahaman mahasiswa kembali dosen memberi pertanyaan tertulis yang harus dijawab sendiri oleh mahasiswa. Langkah ini bertujuan untuk melihat seberapa besar pemahaman mahasiswa tentang bahan bacaan bahasa Inggris.

\section{Proses Implementai Penelitian Tindakan}

Penelitian tindakan pada hakikatnya termasuk jenis penelitian kualitatif, oleh sebab itu, penelitian ini lebih menekankan proses dari pada hasil penelitian yang dicapai. Namun, hasil penelitian tidak berarti bisa diabaikan. Dengan kata lain, penelitian tindakan menitikberatkan pada proses dari pada produk. Dengan demikian, pembahasan tentang proses pelaksanaan penelitian lebih dikedepankan, baru kemudian hasil yang dicapai oleh penelitian tindakan tersebut.

Setelah pemeriksaan kondisi awal dan perencaan penelitian tindakan, kemudian dilakukan implementasinya yakni pelaksanaan suatu aksi yang sudah direncanakan terlebih dahulu dalam kegiatan belajar-mengajar. Proses kegiatan ini dimaksudkan agar penelitian menjadi jelas, konkrit, dan objektif. Dari sini pula akan dapat dilihat sejauh mana perencanaan dapat terwujud atau tidak. Proses implemetasi program aksi tersebut adalah: Pertama, dosen menyusun langkah-langkah pembelajaran dalam bentuk Satuan Acara Perkuliahan (SAP). Pembuatan SAP didasarkan pada silabus mata kuliah bahasa Inggris yang sudah tersedia. Kedua, dosen melaksanakan pembelajaran untuk penelitian ini sebanyak 8 pertemuan dari 14 pertemuan yang direncakan dalam satu semester. Ketiga, dosen memulai penelitian dengan memberi tes awal kepada mahasiswa untuk melihat kondisi awal mahasiswa dan situasi belajarnya. Berdasarkan kondisi awal penelitian ini, masalah diidentifikasi dan alternatif pemecahan masalah dapat disusun dengan cara melakukan perencanaan perbaikan pembelajaran. Untuk itu berbagai unsur yang terkait dengan perbaikan pembelajaran 
dibahas yakni siklus dan langkah-langkah pembelajaran, kolaborator dan saran mahasiswa, serta refleksi. Keempat, dosen 
menerapkan beberapa teori untuk mengimplementasikan program aksi dalam skulus yang sudah ditentukan misalnya penerapannya di lapangan seperti pada Swalayan Mall, Pasar dan tempat keramaian lainnya. Kelima, dosen memberi tes akhir (post test) untuk melihat peningkatan psikologi belajar bahasa Inggris mahasiswa dalam memahami bahan bacaan otentik bahasa Inggris.

\section{Refleksi terhadap Program Aksi}

Refleksi terhadap program aksi merupakan kegiatan evaluasi yang bertujuan menilai keberhasilan dan kefektifan suatu implementasi langkah-langkah pada suatu aksi yang terangkum dalam suatu siklus dan program aksi. Dimana refleksi yang dilakukan setelah pelaksanaan pembelajran dan observasi. Refleksi tersebut dapat dilkaukan pada (1) evaluasi terhadap implementasi program aksi, dan (2) evaluasi terhadap efektivitas implementasi prohgram aksi dalam meningkatkan pemahaman wacana bacaan melalui materi otentik dan belajar mandiri.

\section{Evaluasi terhadap Efektifitas Implementasi Program Aksi dalam Meningkatkan Psikologi Belajar Bahasa Inggris}

Berkenaan dengan implementasi program aksi dalam bentuk pembelajaran mata kuliah bahasa Inggris dalam rangka meningkatkan pamahaman mahasiswa terahadap bahan bacaan otentik bahasa Inggris diperlukan hasil kondisi awal dan kondisi akhir pembelajran untuk dianalisis. Dari perbedaan kedua kondisi tersebut dapat diketahui efektifitas dari implemetasi program aksi terhadap peningkatan pemahaman membaca.

Peningkatan psikologi belajar bahasa Inggris melalui bahan bacaan otentik dapat dilihat secara kualitatif dan kuantitatif. Secara kualitatif, peningkatan psikologi belajar bahasa Inggris melalui bahan bacaan otentik bahasa Inggris dapat dilihat dari komentar kolaborator yang menyatakan bahwa pada kondisi awal mahasiswa masih terasa sulit memahami materi bacaan dan mahasiswa belum siap untuk mengikuti pembelajaran membaca. Pada kondisi akhir mahasiswa sudah mulai memahami isi bacaan dan kelihatan lebih aktif dan antusias. Sehingga kolaborator sampai memberi sarran supaya cara-cara yang diterapkan untuk kelas ini, juga diterapkan untuk kelas reguler lainnya. Hal ini berati terjadi peningkatan psikologi belajar bahasa Inggris mahasiswa terhadap bacaan otentik bahasa Inggris.

Demikian juga dilihat dari saran, kesan dan kritik mahasiswa sebahagian besar mahasiswa menhyatakan sran, kesan dan kritik yang positif, hanya sebahagian kecil mahasiswa yang memberikan saran, kesan dan kritik negatif. Ini artinya terdapat peningkatan pemahaman mahasiswa tentang bacaan otentik bahasa Inggris. 
Selain hal-hal di atas, bukti yang lebih konkrit lagi adanya peningkatan psikologi belajar bahasa Inggris melalui bahan bacaan otentik 
bahasa Inggris mahasiswa dapat dilihat dari perbedaan hasil tes awal dan tes akhir. Hasil tes awal menunjukkan bahwa nilai rata-rata sebesar 41,7 sedangakn hail tes akhir seesar 83,2. Ini menunjukkan terdapat peningkatan yang berarti dari kondisi awal ke kondisi akhir.

Secara kuantitatif, peningkatan pemahaman bahan bacaan otentik evaluasi dilakukan seperti penelitian kuasi eksperimen. Desain yang diterapkan adalah Paired Test Design. Untuk menyatakan perbedaan kondisi awal dan kondisi akhir dapat diketahui lewat uji t. Setelah analisis dilakukan dengan uji t maka diketehaui bahwa nilai $\mathrm{p}=0,000$ pada taraf signifikansi $\alpha=0,05$. Ini berarti bahwa terdapat perbedaan rata-rata yang signifikan antara kondisi awal dan kondisi akhir. Dengan kata lain, terdapat peningkatan yang sangat menonjol pada psikologi belajar bahasa Inggris melalui bahan bacaan otentik bahasa Inggris mahasiswa. Dimana terlihat pada kondisi awal rata-rata nilai mahasiswa 41,7 pada siklus 1 meningkat menjadi rata-rata 66,85 dan pada siklus kedua atau kondisi akhir mencapai 83,2 .

\section{Hasil Observasi}

Analisa komprehensif secara singkat dan umum sering dipahami sebagai cara atau jalan yang ditempuh seseorang dalam melakukan suatu kegiatan berkaitan dengan psikologi belajar, metode tertentu dipakai untuk mengumpulkan berbagai data dan informasi penting yang bersifat psikologis dan berkaitan dengan proses pembelajaran (Tohirin, 2005).

Riset-riset psikologis berkenaan dengan pembelajran Bahasa Inggris, memanfaatkan metode tertentu, seperti (1) eksperimen, (2) kuesioner, (3) studi kasus, (4) penyelidikan klinis, (5) observasi naturalistic (Tohirin, 2005).

Dalam observasi penelitian ini antara peneliti dan para kolaborator mengadakan diskusi berdasarkan pemantauan dan catatan-catatan peneliti sebagai dosen mereka. dimana perlu diketahui juga bahwa hasil observasi adalah akibat dari pelaksanaan pembelajaran yang dimulai dengan implementasi pembelajran setelah tahap awal.

Peningkatan pemahaman mahasiswa terhadap bacaan otentik bahasa Inggris dapat dilihat dari hasil observasi kolaborator. Dari komentar dan saran kolaborator sebagai hasil dari observasi membuktikan bahwa terdapat peningkatan pemahaman mahasiswa terhadap bacaan otentik bahasa Inggris. Hal ini dibuktikan oleh komentar kolaborator yang menyatakan bahwa mahasiswa sudah mulai memahami isi bacaan.

Observasi kolaborator di atas dikuatkan oleh pernyataan mahasiswa yang dikumpulkan melalui angket. Sejumlah 17 mahasiswa ternyata memiliki kesiapan untuk mengikuti perkuliahan. Sedangkan 3 mahasiswa menyatakan kurang siap. Ini berarti data yang dikumpulkan melalui angket 
menggambarkan adanya peningkatan psikologi belajar bahasa Inggris mahasiswa. Di samping dari observasi dan angket, peningkatan psikologi 
belajar bahasa Inggris mahasiswa juga dapat dillihat dari selisih hasil tes awal dan tes akhir. Setelah dianalisis melalui uji t, ternyata terdapat peningkatan yang signifikan dari tes awal dan tes akhir dengan nilai $p=0,000$ pada taraf signifikansi $\alpha=0,05$. Artinya peningkatan psikologi belajar bahasa Inggris mahasiswa terhadap bacaan otentik bahasa Inggris sangat berarti.

Dari segi metode mengajar, hasil observasi menunjukkan bahwa belajar mandiri ternyata dapat meningkatkan psikologi belajar bahasa Inggris mahasiswa. Hal ini ddibuktikan dari hasil observasi kolaborator yang menyatakan bahwa belajar mandiri sebaiknya juga diterapkan untuk kelas reguler lainnya. Hal ini berarti belajar mandiri dapat meningkatkan psikologi belajar bahasa Inggris mahasiswa. Hal ini dikuatkan lagi dari hasil angket mahasiswa di mana 17 mahasiswa menyatakan bahwa belajar mandiri cocok diterapkan dalam meningkatkan psikologi belajar bahasa Inggris mahasiswa. Sedangkan hanya 3 mahasiswa yang menyatakan belajar mandiri kurang sesuai untuk meningkatkan psikologi belajar bahasa Inggris mereka. demikian halnya jika dilihat dari hasil tes membaca mahasiswa yang menunjukkan harga $\mathrm{p}=0,000$ pada taraf signifikansi 0,05 . Hal ini berarti belajar mandiri secara keseluruhan dapat meningkatkan psikologi belajar bahasa Inggris dalam memahami bacaan otentik bahasa Inggris.

Dari segi materi, hasil observasi kolaborator menunjukkan bahwa materi yang diberikan kepada mahasiswa sudah cocok untuk meningkatkan psikologi belajar bahasa Inggris mahasiswa. Hal ini dibuktikan dari pernyataan kolaborator yang mengatakan bahwa materi dapat dipahami mahasiswa. Demikian juga halnya pernyataan mahasiswa yang dikumpulkan melalui angket bahwa 18 orang menyatakan bahwa materi sudah sesuai untuk meningkatkan psikologi belajar bahasa Inggris mahasiswa. Hanya 2 orang mahasiswa yang menyatakan materi kurang sesuai meningkatkan psikologi belajar bahasa Inggris mahasiswa.

\section{DISKUSI}

Pada akhirnya pelaksanaan riset aksi mengenai peningkatan psikologi belajar bahasa Inggris melalui materi otentik dalam penelitian ini dapat disimpulkan sebagai berikut:

1. Upaya Peningkatan Psikologi Belajar Bahasa Inggris melalui Materi Otentik

Agar dapat meningkatkan psikologi belajar bahasa Inggris melalui materi otentik bahasa Inggris yang dilakukan adalah (a) menumbuhkan minat baca, (b) menerapkan berbagai strategi belajar mengajar, dan (c) strategi menggunakan kamus yang menunjang proses membaca dimana hal ini juga dapt membantu terlaksananya proses kognitif dalam belajar sehingga meningkatkan kepercayaan diri mahasiswa. 
Dalam melaksanakan pangajaran, pengajar telah berusaha dengan keras untuk dapat meningkatkan mutu kinerjanya, oleh karena itu pengajar melakukan penelitian yang dapat meningkatkan mutu kerjanya. Oleh karena itu pengajar melakukan penelitian tindakan karena penelitian tindakan adalah suatu bentuk penelitian untuk memperbaiiki dan meningkatkan mutu kinerja (Kemmis dan Mc Taggart, 1990). Dengan meningkatkan mutu kinerja, berati juga meningkatkan mutu bekerja, sehingga peningkatan mutu itu sangatlah penting.

Dan sebagaimana telah diketahui oleh peneliti tertera bahwa peningkatan hasil belajar sangat mencolok antara kondisi awal dan kondisi akhir dari penelitian tindakan ini. Peningkatan tersebut ditandai dengan perolehan nilai yang diperoleh, kesimpulan dan evaluasi sesuai dengan acuan dan kriteria penilaian. Bahwa mahasiswa harus dapat menemukan sesuatu sesuai dengan pribadi mengenai materi dan media pembelajaran, pembelajar mengakui bahwa dengan materi dan media yang menarik, maka akan dapat memotivasi dalam proses belajar sehingga dapat memacu belajar. Dengan melakukan tindakan turun langsung ke tempattempat keramaian seperti mall, swalayan dan lainnya pembelajar dapat mempraktikkan antara teori yang mereka pernah dapatkan dengan penerapan kehidupan sehari-hari.

2. Peningkatan Pemahaman Wacana melalui Materi Otentik

Penerapan materi dalam penelitian ini mengikuti hal-hal sesuai dengan tujuan belajar, bagi mahasiswa, dan sesuai antara wacaan dan mahasiswa serta mengikuti situasi ahli pembelajaran. Berdasarkan hasil penelitian maka dapat diambil kesimpulan bahwa materi yang tepat dan baik untuk perkembangan pengetahuan yang cocok serta sesuai dengan kondisi usia mahasiswa yang rata-rata berusia di atas 17 tahun ke atas dan latar belakang mereka masuk ke fakultas syariah dan hukum adalah calon hakim agama dan ahli ekonomi syariah aalah materi bacaan otentik.

Hal ini dapat dipertegas berdasarkan analisis hasil tulisan mahasiswa tentang psikologi belajar bahasa Inggris mereka mengalami peningkatan nilai rata-rata yang tinggi dibandingkan bila menggunakan materi umum yang biasa mereka gunakan sebagai buku ajar atau pegangan di kelas, juga dapat dipertegas dengan peningkatan rasa keberminatan mereka terhadap perkuliahan bahasa Inggris yang tinggi berdasarkan komentar atau wawancara yang telah dilakukan pada penelitian ini. Mengenai materi dan media pembelajaran, mahasiswa mengakui bahwa dengan materi dan media yang menarik, maka akan dapat memotivasi dalam proses belajar mengajar sehingga akan dapat memacu belajar. 


\section{DAFTAR PUSTAKA}

Kemmis S and R. Mc. Taggart. (1990). The Action Research Planner. Geelong: Deakin University

Lewis Michael and Jimmie Hill. (1985). Practical Teachniques for Language Teaching. Great Britain.

Muhibbi Syah, M.Ed. (1998). Psikologi Belajar. Jakarta : LOGOS Cahaya Ilmu

Oemar, Hamalik. (2000). Psikologi Belajar dan Mengajar. Jakarta: Sinar Baru Algensindo

Paul, Suparno. (1997). Filsafat Konstruktivisme dalam Pendidikan. Yogyakarta: Kanisius

Simnajuntak, B dan Pasaribu IL. (1981). Psikologi Perkembangan. Bandung: Tarsito

Slameto. (1995). Belajar dan Faktor-Faktor yang Mempengaruhinya. Jakarta: Rineka Cipta

Suryabrata, Sumadi. (1987). Psikologi Pendidikan. Jakarta: Rajawali Press

The Holy Qur'an. (1410 Hijriah). English translatien of the meaning and comanatry. Madina: IFTA, Call and Guidance, King Fahd Hay Qur'a Printing Complex

Tohirin. (2005). Psikologi Pembelajaran Bahasa Inggris. Jakarta: Rajawali Press 
